\title{
盲腸固定術の遠隔成績について
}

\author{
大森赤十字病院 ” \\ 仲 \\ 原 \\ 宽 \\ Hiroshi Nakahara \\ 牧克克 \\ Katumi Maki
}

\section{I まえがき}

私共は大森赤十字病院にて昭和 28 年 8 月より炤和 31 年 12 月までに移動幽盲腸飞対し施行した盲腸固定 術の遠隔成績について調查したので，そのあらましを 述べる。調查方法柱復八ガキによるアンケートで全 症例 20 例中 16 例の回答が得られた。

\section{II 主訴亡症状 (術前)}

右下, 側腹部の鈍痛, 压痛及び不快感と便通の不定 （秘結）が㤝とえど全症例を占めている。主訴を訴兄 てより来院なでの期間は 1 月〜 4年でその間種々の内 科的治療も無効のものが多かつた。

性別で梳性が 15 例, 男性 5 例である。

年䕆別で江 19 才以下 1 例, 20〜29才 12 例, 30 39 才 5 例，40才以上が 2 例であつた。

自覚的症状は持続的或は間歇的の右下, 睢腹部の疼 痛, 便通の秘結 (2 3 日飞 1 行) 並び食思不振が 多かつた。又排便により症状の軽快するものがかなり 合まれていた。

他覚的症状は右下側腹部の圧痛一Mac. Burney氏点 より上行結腸中央部に及ぶ圧痛を俧めるすのが多く， 時に屎塊による腸詰樣腫瘤を触知した。

\section{III 診断と手術}

まず一般検查により泌袏器, 子宮附属器及び消化器 の炎症, 結石, 腫湯並びに寄生虫定を除外した後, 造 影威使用によるX線透視で回宣部及び上行結腸の異常 可動性を確めた。

手術方法は主として副直腹笳切開にて腹腔に達し， 虫垂切除ののち Wilms 氏法及びその変法一広く上行 結腸全長に亘り肝等曲附近まで固定一により後腹膜に 固定した。

切除虫垂はほとしど肉眼的, 組織学的に異常を認め ないすのが多かつたが，萧石，萎縮，虫垂間膜の般 痕による屈曲が 数例に見られた。又肝䝮曲の下垂と Jackson 氏膜の形成が数例飞瑟められた事が注目され to

\section{IV 遠 隔 成 績}

1. 自覚症状の消失したもの 4例，軽快したもの9: 例, 不変の子の 3 例, 增臺なし。

2. 便通は正常 (1日 1行) になつたすの 10 例,

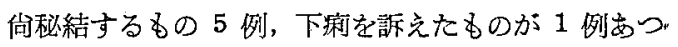
た。

3. 食思は良好となつたもの 9 例, 普通 6 例, 不良 1 例であつた。

4. 体重は術前より増加（平均 $2.5 \mathrm{~kg}$ ) 9 例, 不変 3 例, 減少 2 例, 不明 2 例であつた。

5. 腰痛は術前 2 例であつたが術後 1 例増加した。

6. 月経は順調なるすの8例，不順なるすの4例で あつた。

術後罯㭧した病気は特核及び中耳炎が各 1 例めつ た。

\section{$\mathbf{V}$ 考察}

盲腸の可動性については正常亡異常の境界を明確に 定めることは極めて困難である。検者の主観によつて も或る程度左右されるし, 又成書沉もとの明確な記載:

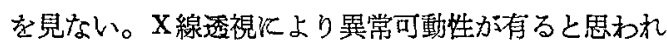
るるのでも何等愁訴の無いものが多い。

そこで私共は愁訴のある者のうち，回盲部の可動性

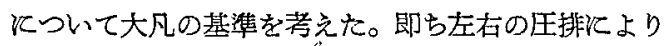
目腸が正中線を越总，立位にて上下飞 6 横指以上移動 するものを移動性盲腸之診定した。

一般江移動性盲腸は 20 30才台の女性, 殊江無力 性体筫で神経躓のるのに多いといわれているが，私共 の症例子大体一致していた。術前の徬断之開腹時所見 は全例を通じ略正確であつた。移動性盲腸は内臟下垂 证の部分症状であり無力性体質に伴う一種の精神々経 症状であるから，その固定をはかつて子症状の軽快を 見婸合が少くないという者もいる。しかし私共の成 績を検討するに症状の改善されたるのが大多数を占。 
$-90-(680)$

め，固定術の効果は比較的良好であると考学る。食思 の良否, 体重の堌減, 腰痛の有無及び月経の順, 不順 壮種々の因子に左右されるすのであるから，今後更に 調査の方法を研究したい。

\section{VI 結 語}

私共は過去 4 年間当院にて施行した盲腸固定術の遠 滆成績を調查し次の結諭を得た。
術前の患者の主挀は術後大部分消失または減退し再 発をみない点から，術前の検查を充分にして手術の適 応を俱らなければ，盲腸固定術は有效であると考兵ら れる。

終りに御指導を賜つた下妻院長に深謝致します。

文献

日本臨获：13(2)，95(1955) 